Ann. Biol. anim. Bioch. Biophys., 1978, 18 (4), 1019-1025.

\title{
Ultrastructural studies on experimentally induced vitellogenesis in juvenile rainbow trout (Salmo gairdneri R.)
}

\author{
par S. N. UPADHYAY, B. BRETON, R. BILLARD \\ Laboratoire de Physiologie des Poissons, I. N. R. A., \\ 78350 Jouy en Josas, France.
}

Summary. Juvenile rainbow trout (weighing 10 or $20 \mathrm{~g}$ ) were treated thrice weekly for 10 weeks with salmon-gonadotropin (S-GTH), salmon pituitary extract (S-PE), S-GTH plus estradiol-17 $\beta$, and estradiol-17 $\beta$ alone. The effects of these treatments on the oocytes were studied at ultrastructural level.

Saline-injected control fish contained oocytes at previtellogenic stage of development. S-GTH $(0.1$ or $0.5 \mu \mathrm{g} / \mathrm{g})$ induced a synthesis of endogenous yolk in the oocyte cytoplasm but failed to initiate incorporation of exogenous yolk or vitellogenin into the oocytes. S-GTH $(0.1 \mu \mathrm{g} / \mathrm{g})$ in combination with estradiol-17 $\beta(1 \mu \mathrm{g} / \mathrm{g})$ produced similar results to those with S-GTH alone. Estradiol-17ß alone failed to induce vitellogenesis. In contrast, S-PE $(10 \mu \mathrm{g} / \mathrm{g})$ induced the incorporation of exogenous yolk into the oocyte indicated by an extensive pinocytotic activity at the oocyte membrane.

It is suggested that gonadotropin is necessary for the induction of endogenous yolk synthesis and that some other pituitary hormone(s) is involved in the process of incorporation of exogenous yolk or vitellogenin into the oocyte.

\section{Introduction.}

Vitellogenesis has been regarded as a process of yolk accumulation in the oocyte. During this process a part of the yolk is synthesized in the oocyte cytoplasm by various organelles (Raven, 1961 ; Norrevang, 1968) ; the rest of the yolk material is synthesized at an extra-ovarian site and then transported via circulation to the ovary and finally deposited into the oocyte by the process of pinocytosis (Norrevang, 1968 ; Wallace and Bergink, 1974).

The influence of pituitary on vitellogenesis has been demonstrated in several teleost species; hypophysectomy results in the degeneration of yolky oocytes and replacement therapy using pituitary extracts reinitiates viłellogenesis (de Vlaming; 1974). However, the number of pituitary hormones involved in the regulation of vitellogenesis in teleosts is still controversial.

This report presents the effects of purified salmon-gonadotropin, salmon pituitary extract and estradiol-17 $\beta$ on the oocyte development in juvenile rainbow trout (Salmo gairdneri) with a view to finding out whether vitellogenesis can be induced experimentally in juvenile fish and the number of pituitary hormones involved in this process. 


\section{Materials and methods.}

Juvenile rainbow trout (Salmo gairdneri R) weighing aproximately 10 or $20 \mathrm{~g}$ were injected thrice weekly for 10 weeks with salmon-gonadotropin (S-GTH) male and female $(0.1 \mu \mathrm{g} / \mathrm{g}$ and $0.5 \mu \mathrm{g} / \mathrm{g}$ body weight), S-GTH $(0.1 \mu \mathrm{g} / \mathrm{g})$ plus estradiol-17 $\beta$ $(1 \mu \mathrm{g} / \mathrm{g})$, salmon pituitary extract male and female $(10 \mu \mathrm{g} / \mathrm{g})$, estradiol-17 $(1 \mu \mathrm{g} / \mathrm{g})$, and fish saline (0.9 p. 100).

Salmon-gonadotropin was purified from male and female Onchorynchus tshawytscha pituitaries. The purification procedure for S-GTH has been described elsewhere (Breton, Prunet and Reinaud, 1978). Salmon pituitary extract (S-PE) was prepared by homogenizing male and female $O$. tshawytscha pituitaries in a glass-teflon homogenizer. Estradiol-17 $\beta$ was obtained from Steraloids (USA).

At the end of treatment, the fish were killed by decapitation. Small pieces of ovary were immediately put in a fixative containing paraformaldehyde (1 or 2 p. 100), glutaraldehyde ( 2 or 3 p. 100) and picric acid (0.1 p. 100) in $0.15 \mathrm{M}$ cacodylate buffer $\mathrm{pH} \mathrm{7.3,} \mathrm{for} 2 \mathrm{hrs}$ at room temperature followed by post-fixation in $1 \mathrm{p} .100$ osmium tetraoxide in the same buffer for 1 hour at room temperature. After dehydration tissues were infiltrated and embedded in an epon-araldite mixture. Ultrathin sections stained with uranyl acetate and lead citrate were observed under a Siemens Elminskop.

\section{Results.}

Saline-injected control fish contained oocytes measuring 43 to $130 \mu$ in diameter. All the oocytes were at previtellogenic stage of development as no evidence for yolk accumulation was observed in their cytoplasm.

S-GTH purified from male and female pituitaries had similar effects on oocyte development. The oocytes in S-GTH-(0.1 or $0.5 \mu \mathrm{g} / \mathrm{g})$ treated fish measured up to $495 \mu$ in diameter. A correlation was observed between the oocyte diameter and stage of development. Apart from previtellogenic oocytes, the more advanced oocytes could be classified into three categories on the basis of their diameter : small (175 to $233 \mu)$, medium $(285$ to $350 \mu)$, and large $(400$ to $495 \mu)$. The small oocyles were characterized by the presence of multi-vesicular bodies (MVB) at the perinuclear cytoplasm (fig. 1). The medium-sized oocytes exhibited lipid bodies in addition to the MVB. These lipid bodies were found scattered amongst the MVB (fig. 2). The large oocytes

Electron microgrophs of portions of oocyfe from the ovary of juvenile rainbow frout treated with salmongonadotropin.

FIG. 1. - A large number of multi-vesicular bodies (MVB) are seen around the oocyle nucleus $(N)$.

FIG. 2. - Lipid bodies (LB) are found scaftered amongst the multivesicular bodies (MVB).

FIG. 3 and 4. - Multi-vesicular bodies (MVB) and lipid bodies (LB) are dispersed in the cytoplasm. Note large lipid bodies exhibiting concentric zonation. $N$ : oocyte nucleus.

FIG. 5. - Oocyfe bound with a basal lamina (BL) and a single loyer of follicle cells (FC). Note microvilli (MV) projecting from the oocyte surface. 
had MVB and lipid bodies dispersed throughout the cytoplasm (fig. 3 and 4). The most obvious difference observed in the oocytes of this size range was that the lipid bodies exhibited concentric zonation (fig. 3 and 4). In all the three categories of oocytes no zona radiata was formed and no evidence for the deposition of exogenous yolk by the process of pinocytosis was observed (fig. 5). Therefore, MVB and lipid bodies can be considered as constituent of endogenous yolk formed in the oocyte cytoplasm in response to S-GTH treatment.

Treatment with S-GTH $(0.1 \mu \mathrm{g} / \mathrm{g})$ in combination with estradiol-17 $\beta(1 \mu \mathrm{g} / \mathrm{g})$ produced similar results as described for the treatment with S-GTH alone. However, treatment with estradiol-17 $\beta$ alone did not initiate synthesis of endogenous yolk in the oocyte cytoplasm.

The oocytes of fish treated with S-PE $(10 \mu \mathrm{g} / \mathrm{g})$ were considerably advanced as compared to those seen after treatment with S-GTH alone or in combination with estradiol-17 $\beta$. The oocytes measuring 580 to $787 \mu$ in diameter were characterized by the formation of a distinct and continuous zona radiala (fig. 6), cytoplasmic vesicles (probably yolk vesicles) of variable sizes distributed throughout the cytoplasm (fig. 7), and an extensive pinocytotic activity at the oocyte membrane (fig. 8). The induction of pinocytotic activity following S-PE treatment indicates the incorporation of exogenous yolk or vitellogenin into the oocyte. S-PE prepared from male and female pituitaries had similar effects.

\section{Discussion.}

This study demonstrates that S-GTH, whether purified from male or female pituitaries, does not differ in its qualitative properties. S-GTH $(0.1$ or $0.5 \mu \mathrm{g} / \mathrm{g})$ induces an endogenous synthesis of yolk in the oocyte cytoplasm but fails to initiate the incorporation of exogenous yolk into the oocyte which would be necessary for the completion of vitellogenesis. S-GTH in combination with estradiol-17 $\beta$ has a similar effect on the oocyte development. Estradiol-17 $\beta$ alone does not induce vitellogenesis. In contrast, S-PE treatment induces an extensive pinocytotic activity at the oocyte membrane in addition to an endogenous synthesis of yolk in the oocyte cytoplasm. The pinocytotic activity has been considered as an indicative of the incorporation of exogenous yolk or vitellogenin into the oocyte (Wallace and Bergink, 1974).

A comparison of these results suggests that there may be other pituitary hormone(s) involved in the process of the incorporation of exogenous yolk or vitellogenin

Electron micrographs of portions of oocyfe from the ovary of juvenite rainbow trout freated with salmon-pituitary extract.

FIG. 6. - A continuous zona radiata (ZR) is observed between follicle cells (FC) and the oocyfe (OC).

FIG. 7. - Oocyte cyfoplasm showing yolk vesicles (YV).

FIG. 8. - Zona radiata (ZR) is composed of an inner zone of vifelline membrane (VM), an oufer zone of microvilli (MV). Note extensive pinocytotic activity at oocyte periphery. Pinocytotic vesicles (PV) arise at the base of microvilli (arrow). 


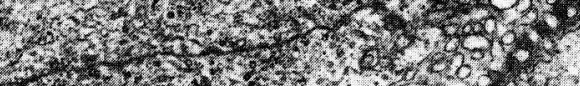

FC $100,15 \%$ 1.1. 2736

(5)

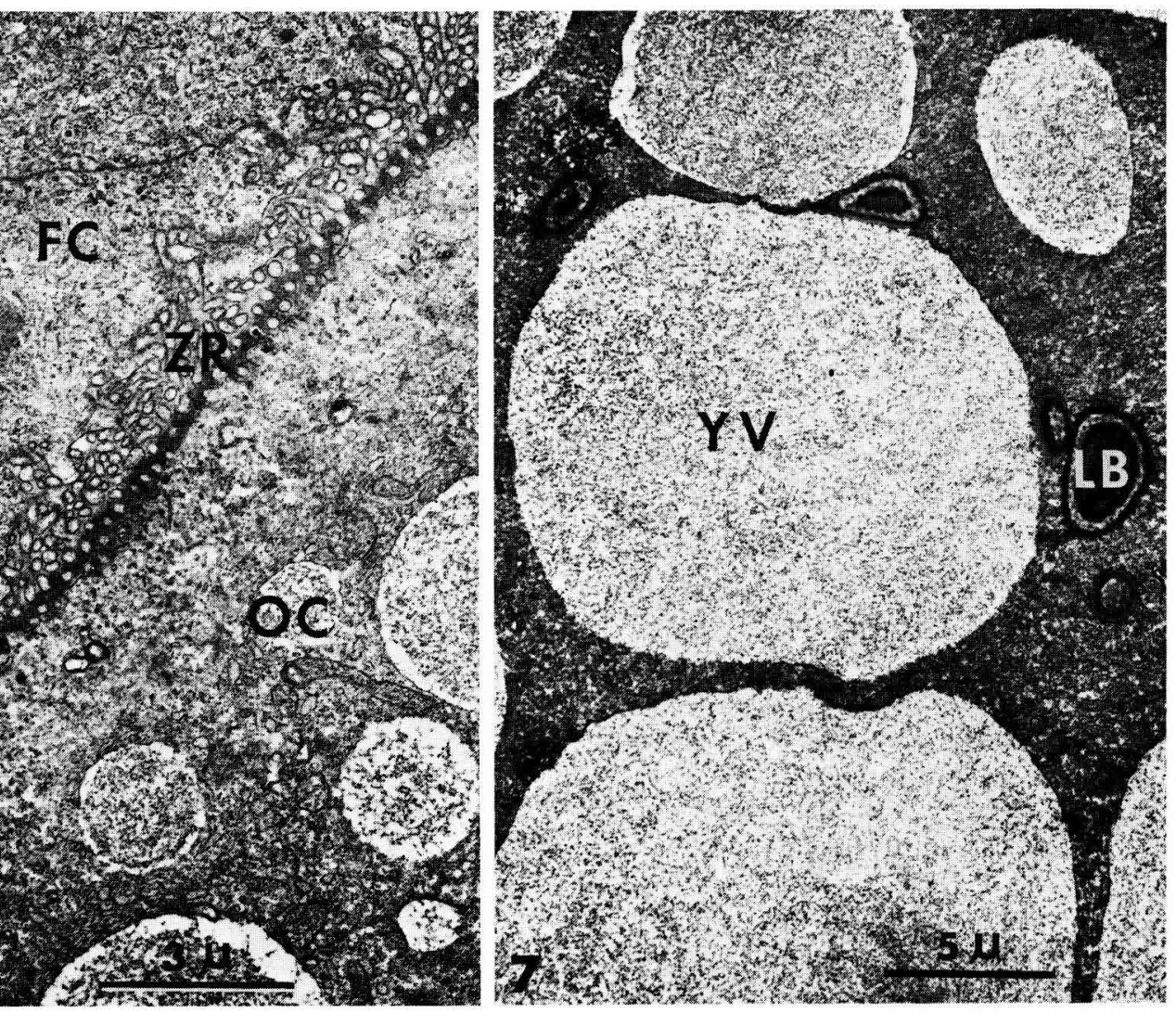

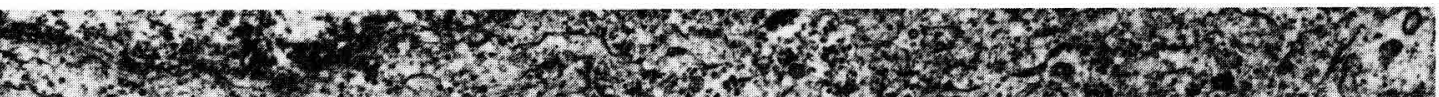

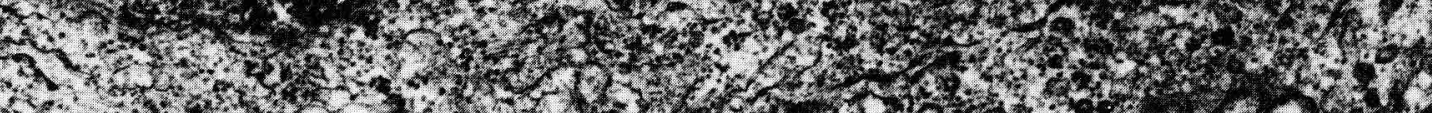

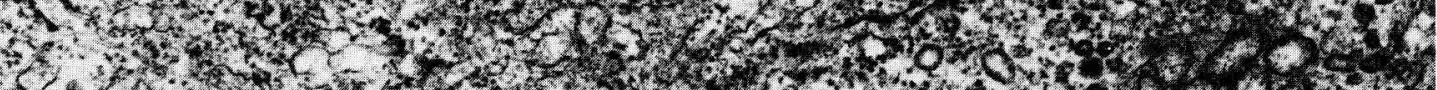

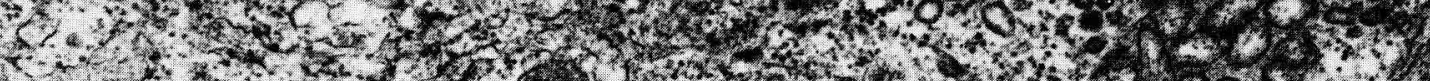

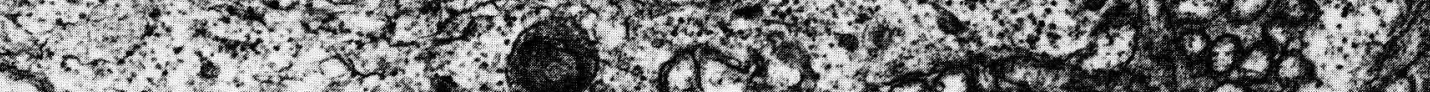

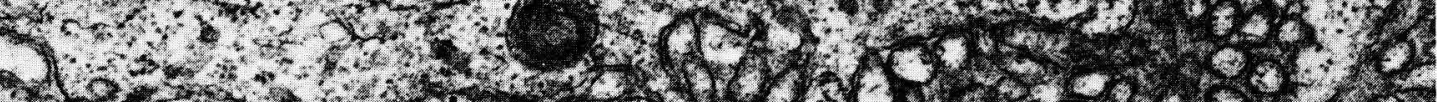

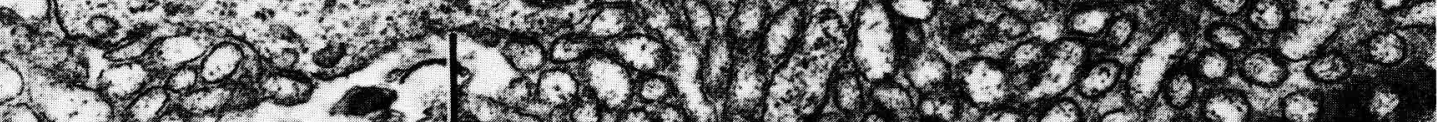
800350

180

(1)

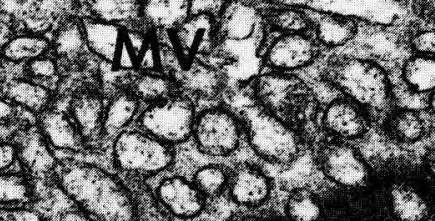

10198:

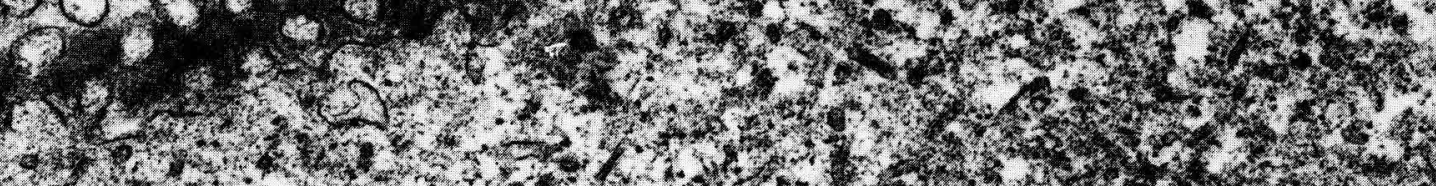
P. Por.t.

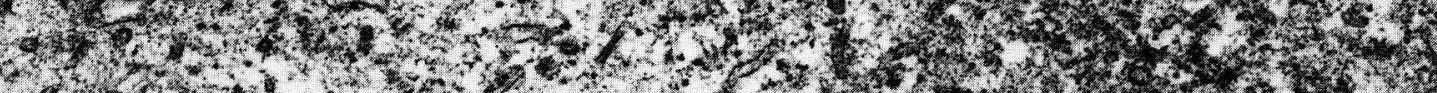

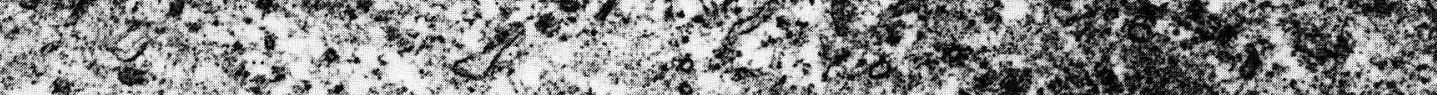

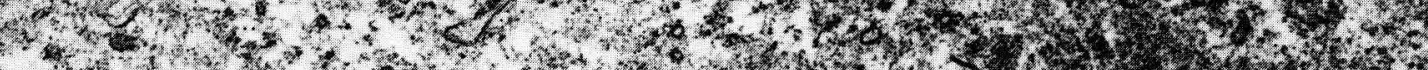

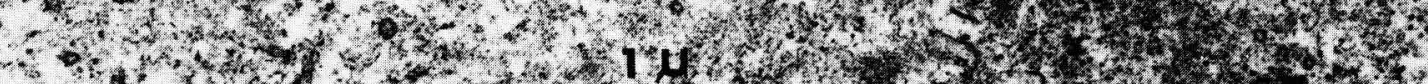

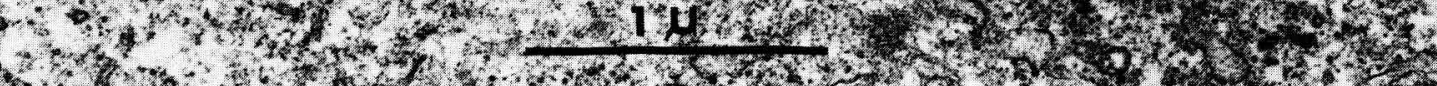

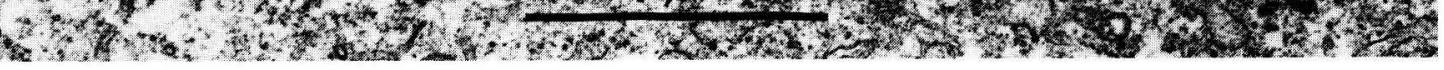


into the oocyte, which may act alone or in synergism with gonadotropin. Campbell and Idler (1976) reported that a glycoprotein fraction from the pituitary of Hippoglossoides platessoides containing gonadotropic activity failed to stimulate incorporation of yolk in the hypophysectomized Pseudopleuronectus americanus; in contrast a nonglycoprotein fraction of these pituitaries stimulated yolk incorporation into the ovary.

The present results are in contrast to the conclusions of Donaldson (1973) and Burzawa-Gérard (1974), who believe that a single pituitary gonadotropin is capable of stimulating all the processes related to oocyte development in teleosts.

S-GTH has been found to stimulate the steroidogenic features of ovarian interstitial cells and protein synthetic activity in the liver parenchymal cells of female juvenile rainbow trout (Upadhyay, 1977) ; the latter action is most probably mediated by ovarian estrogens.

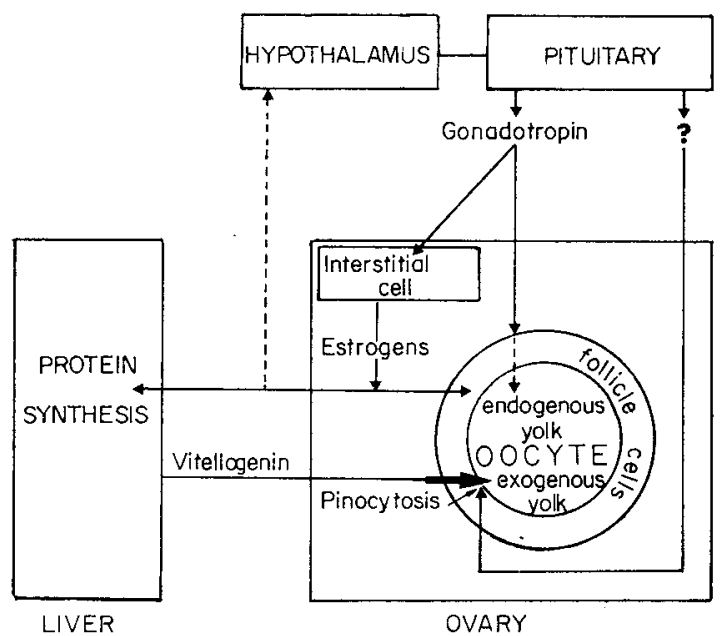

FIG. 9. - Generalized scheme showing major vitellogenic relationship and response of Salmo gairdneri.

In conclusion, the major vitellogenic responses and relationships in rainbow trout are illustrated schematically in figure 9.

Symposium sur la Reproduction des Poissons Paimpont, France, 19-21 septembre 1977.

Acknowledgments. - This work was partly supported by the CNEXO, grant No 77-1619.

Résumé. Des truites Arc-en-ciel juvéniles pesant entre 10 et $20 \mathrm{~g}$ ont reçu trois fois par semaine pendant 10 semaines des injections intrapéritonéales de gonadotropine de saumon $(\mathrm{S}-\mathrm{GTH})$, des extraits hypophysaires (S-PE), de S-GTH + estradiol $17 \beta\left(\mathrm{E}_{2}\right)$ et $\mathrm{E}_{2}$ seul. Les effets de ces traitements sur les ovocytes ont été observés en microscopie électronique.

Les animaux témoins recevant une solution saline ont des ovocytes au stade prévitellogenèse. S-GTH $(0,1$ or $0,5 \mu \mathrm{g} / \mathrm{g})$ induit une synthèse de vitellus endogène dans le cyłoplasme de l'ovocyłe, mais ne peut induire l'incorporation de vitellus exogène ou vitello- 
génine dans les ovocytes. S-GTH $(0,1 \mu \mathrm{g} / \mathrm{g})$ associé à $E_{2}$ produit des effets similaires à S-GTH seule. Au contraire S-PE $(10 \mu \mathrm{g} / \mathrm{g})$ induit l'incorporation de vitellus exogène dans l'ovocyte comme l'indique une intense activité de pinocytose au niveau de la membrane de l'ovocyte.

II est suggéré que. GTH est nécessaire pour l'induction de la syhthèse endogène de vitellus et qu'une ou plusieurs autres hormones; hypophysaires sont impliquées dans l'incorporation du vitellus exogène dans l'ovocyłe.

\section{References}

BRETON B., PRUNET P., REINAUD P., 1978. Sexual differences in Salmon gonadotropin. Ann. Biol. anim. Biochim. Biophys., 18, 759-765.

BURZAWA-GÉRARD E., 1974. Ełude biologique et biochimique de l'hormone gonadotrope d'un poisson téléostéen, la carpe (Cyprinus carpio L.). Mém. Mus. Hist. nat., Sér. A, Zool., 86, 1-77.

CAMPBELL C. M., IDLER D. R., 1976. Hormonal control of vitellogenesis in hypophysectomized winter flounder (Pseudopleuronectes americanus Walbaum). Gen. comp. Endocrinol., 28, 143. 150.

DE VLAMING V. L., 1974. Environmental and endocrine control of teleost reproduction, 13-83. In SCHRECK C. B., Control of sex in fishes. Ext. Div. Virginia Polytech. Inst. State Univ., Blacksburg, Virginia, USA.

DONALDSON E. M., 1973. Reproductive endocrinology of fishes. Am. Zool., 13, 909-927.

NORREVANG A., 1968. Electron microscopic morphology of oogenesis. Int. Rev. Cytol., 23, 113-186. RAVEN C. P., 1961. Oogenesis : the storage of developmental information. Pergamon, Oxford.

UPADHYAY S. N., 1977. Morphologie des gonades immatures ef éfude expérimentale de l'induction de la gamétogenèse chez la truife arc-en-ciel juvénile (Salmo gairdnerii R.), Th. Doct. Ełat, Univ. Paris-VI.

WALLACE R. A., BERGINK E. W., 1974. Amphibian vitellogenin : properties, hormonal regulation of hepatic synthesis and ovarian uptake, and conversion to yolk proteins. Amer. Zool., 14, 1159-1175. 